\title{
THE RELATIONSHIP BETWEEN COMMUNICATION AND EDUCATION THROUGH THE CREATIVE PERSONALITY OF THE TEACHER
}

\author{
Vida NAVICKIENE ${ }^{1 *}$, Živilè SEDEREVIČIŪTĖ-PAČIAUSKIENE ${ }^{2}$, \\ Ilona VALANTINAITE் ${ }^{3}$, Viktorija ŽILINSKAITÉ-VYTIENE $\dot{E}^{4}$ \\ 1, 3 Vilnius Gediminas Technical University, Faculty of Creative Industries, \\ Department of Philosophy and Cultural Studies, Traku str. 1, LT-01132 Vilnius \\ 2, 4 Vilnius Gediminas Technical University, Faculty of Creative Industries, \\ Department of Creative Communication, Traku str. 1, LT-01132 Vilnius
}

Received 09 November 2018; accepted 19 February 2019

\begin{abstract}
The article focuses on the relationships of communication and educational processes, creativity aspects in the context of higher education. A creative personality of the teacher determines how smooth and efficient these relationships are. The results of the quantitative research (sample 124 teachers) conducted at Lithuanian higher education institutions and coprehensively presented in the article reveal the attitude of Lithuanian higher education teachers towards the significance of communication in the educational process. Though higher education teachers have to possess various competences such as personal, communication, social, lifelong learning, methodological, planning, organisational, leadership and assessment ones, the respondents distinguished several most significant to them. The research revealed that teachers see personal and communication competences as the most important ones, which also reveal and substantiate close relationships of communication and educational processes. The relationship is enhanced by a creative personality of the teacher, his or her positive personal qualities and values. Higher education teachers not only perceive the significance of communication and educational competences in the educational process but also express a need for their continuous improvement.
\end{abstract}

Keywords: communication competence, creative teacher, educational competence, higher education, teacher communication.

\section{Introduction}

"Communication is seen as social interaction of people while exchanging scientific, industrial or any other experience; interpersonal or group communication among people exchanging their experience with the help of verbal and non-verbal signals" (Jovaiša, 2007, p. 121). The concept of communication is defined in the similar way by the same researcher but the definition is supplemented by the following: "communication starts and finishes a pedagogical

${ }^{\star}$ Corresponding author. E-mail: vida.navickiene@vgtu.lt

This is an Open Access article distributed under the terms of the Creative Commons Attribution License (http://creativecommons. org/licenses/by/4.0/), which permits unrestricted use, distribution, and reproduction in any medium, provided the original author and source are credited. 
act during the lesson and other pedagogical meetings" (Jovaiša, 2007, p. 36). It should be noted that conducting research on communicative skills in certain contexts according to valid methodologies, Ann Bainbridge Frymier and Marian L. Houser (2000, p. 208) singled out eight elements that make up the process of communication between the teacher and the student:

"conversational skill (the ability to initiate, maintain, and terminate enjoyable casual conversations), referential skill (the ability to convey information clearly and unambiguously), ego supportive skill (the ability to make another feel good about himself or herself), comforting skill (the ability to make others feel better when depressed, sad, or upset), conflict management (the ability to reach mutually satisfying solutions in conflicts), persuasive skill (the ability to get people to modify their thoughts and behaviours), narrative skill (the ability to entertain through jokes, gossip, stories, etc.), and regulation (the ability to help someone who has violated a norm to fix the mistake effectively)".

Generalising the definitions provided by the researchers or the elements distinguished by them a direct relationship between communicative and educational competences is observed.

This can also be explained employing the model of the process of linear communication presented by Viktorija Baršauskienè, Junona Almonaitienė, Rosita Lekavičienė, and Dalia Antinienè (2011), which consists of three elements: a sender - a person, who transmits information; a message (information) - what is conveyed, sent, transmitted; a receiver - a person, who receives information. It should be mentioned that in the educational process and under a two-way communication between the teacher/educator (as an information sender) and the student/educatee (as an information receiver), a pedagogical interaction is established that is built namely on the relations. According to Aldona Palujanskienè (2010), relations depend on various physiological, psychical, social aspects and the educator's (information sender's) ability to communicate is one of such aspects. Pedagogical (educational) interaction occurs, when there is mutual exchange of information, an open dialogue between the educator and educatee, and when the educatee cooperates with others. It is important to highlight the dependency of a smooth and efficient communication and educational process on the creative personality of the teacher. According to Irina Petrovna Gladilina (2016, p. 1692, 1698),
"Creativity in professional structure of a higher school teacher is a factor to achieve the prescribed tasks of adults training. Creative approaches to solving professional tasks reflect the creative essence of personality and are manifested not only in person- al creative activity but in creative interaction with trainees. $\langle\ldots\rangle$ As evidenced by the author's experience, a principal factor in successful teaching adults is creative organi- zation of not only the academic process but also creative cooperation at all the stages of communication chain "higher school teacher - learning adult".

One of the aspects of a teacher's creativity is development of new methods, a process which requires a more efficient communication, enhances pedagogical interaction and activates both student and teacher participation in activities. As claimed by Choi Sang Long, Zaiton Ibrahim, and Tan Owee Kowang (2014), teaching creativity and class activity make a positive influence on students' satisfaction.

The relationship between the communication and educational competences in the educational process is presented in Figure 1. 


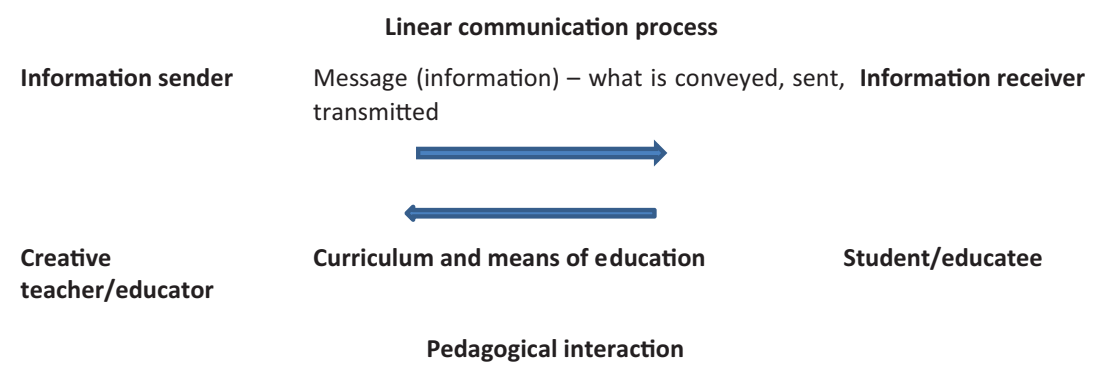

Figure 1. The relationship between the processes of communication and education in the educational process (source: created by authors)

It should be noted that in the processes of communication and education not only the relantionship between the information sender and the receiver but also an environment that is appropriate and favourable for communication and other aspects gain significance. Therefore, creativity to have a dynamic feature, whereby students can develop if teachers provide them with appropriate learning environments (Leikin, 2009). According to psychologist Ala Petrulyte (2008), in order to start speaking, an individual has to feel a need to do it, a motive to convey or write information expressing own emotional state, etc. Kęstutis Pukelis, Izabela Savickienė, Eugenijus Danilevičius, Aušrinè Slavinskienè, Asta Lapėnienė, Giedrè Baltrušaitytė, Eglè Stasiūnaitienè, and Jorūnè Vyšniauskytė-Rimkienė (2011) join the abovementioned opinion and describes a lecture as a way of communication, where teacher's information, gestures, facial expression, body language, eye contact can contribute to or, on the opposite, can impede memorising the presented content. Thus, it can be concluded that teachers, who communicate in the educational process, become conveyers of professional knowledge. They can also have or already have influence on the student as a personality. It is very important because, as Fernando Cardoso de Sousa (2007) points out, creativity, through, lies not in the teacher, nor in the student, but in the interaction between the two. This obliges a teacher to improve subject-specific, educational and communication competences. It should be noted, according to Rimantas Tidikis (2001), that in this process the student masters or merely adopts a thinking style of an authoritative and personally respected teacher, frequently follows the manner of his or her behaviour or speaking, his or her activity or behaviour patterns, develops respect and tolerance for other people. Through such relations a student is evaluated accordingly and is able to express himself or herself, builds up criteria of self-evaluation and value of own personality. Moreover, as claimed by Long, Ibrahim, and Owee Kowang (2014), competences such as knowledge on subject, clarity of presentation, interaction with students, teaching creativity, clarifying learning outcome, class activity and lecture notes are significantly related to student satisfaction.

Thus, in the process of communication, a teacher acquires an important role of an educator, which can influence the student's personality and create prerequisites for adopting the teaching style in the future if such an activity is to be continued, it even makes an influence on learning outcomes. It is important to note that Dejja Aukštkalnyte் (1999), who analysed the communication competence of teachers as a prerequisite for pedagogical communication, also attracted her attention to those processes. In her opinion, pedagogical communication 
differs from personal, organisational and even any other kinds of professional communication as it occurs during the educational activities. The participants in pedagogical communication always consist of a teacher, as an initiator of the process and an educatee, who assumes an active role and provides a meaningful reaction to the teacher's initiative. According to Gönül Yazgan-Sağ and Elçin Emre-Akdoğan (2016), teachers as experts are significant actors in activating creativity in the classroom. Therefore, raising awareness in teachers around creativity and the quality of knowledge is crucial.

Therefore, the article aims to analyse the teachers' attitude towards the importance of communication in the educational process revealing the relationships between communication and education through the creative personality of the teacher.

\section{Methodology}

The higher education system in Lithuania is of binary character and for this reason the survey was carried out in higher education institutions of two types (universities and colleges). The questionnaire survey carried out from September to November in 2015 included 124 respondents (the questionnaire was distributed via e-mail). The questions were answered by $56.5 \%$ of university and $43.5 \%$ of college teachers, who represented 6 scientific fields. The research instrument was designed by the authors of the article seeking to analyse the higher education teachers' attitude to and understanding about the competences necessary for them in the study process and importance of their improvement; several open-ended questions were included among closed-ended questions. Seeking to ensure a probability for each member of population to be included into the sample, simple random sampling selection (probability sampling method) was applied. The research methods included: analysis of scholarly literature, qualitative content analysis (qualitative information obtained from the respondents' answers to open-ended questions were analysed and systemised distinguishing categories, subcategories and presenting respective quotes). The research ethics: the obtained research results were processed without revealing professional or research affiliations of the respondents.

The research sample embraced higher education teachers from all the study areas (social sciences $-38.3 \%$, technological sciences $-24.1 \%$, humanities $-18.4 \%$, bio-medical sciences $7.1 \%$, physical sciences $-7.1 \%$, arts studies $-5 \%$ ).

The analysis of the respondents' positions according to their pedagogical titles revealed that the majority of the participants in the survey are lecturers (52.4\%), the second largest group consists of associate professors (31.5\%), whereas professors (8.9\%) and assistant lecturers $(7.3 \%)$ make up the smallest proportion. The biggest number of respondents $(39.5 \%)$ have accumulated working experience from 11-20 years, $21 \%$ of them have worked from 6 to 10 years, whereas $16 \%$ of the respondents have obtained working experience from 21 to 30 years. The distribution of the teachers according to the age disclosed the biggest group (68\%) of 30-50 years old respondents (51-60 years old teachers comprised $15 \%$, the numbers of other age groups were not significant). These data show that the respondents justified the importance of the necessary competences relying on their working experience $(13.7 \%-5$ years of experience and $8.9 \%$ - over 30 years of experience). 


\section{The results on the survey of higher education teachers}

The teachers from higher education institutions were asked to evaluate, which competences are the most significant to them while working with students. The following interrelated competences possessed by a higher education teacher can be singled out in the educational process: personal (that also embraces creativity), communication, social, lifelong learning, methodological, planning, organisational, leadership and assessment ones (see Figure 2). Therefore, the article focuses on the analysis of the two closely interrelated competences, i.e., personal and communication competences, since they received the highest evaluation and complete each other by human qualities and abilities. As stated by Petrovna Gladilina (2016), development of a higher school teacher's creativity suggests the following: a personality's need for creative activity; creative skills; characterological personal features; individual specifics of psychical processes.

The analysis of the results shows that personal competence, which combines various personal qualities (including creativity) and values, is seen as the most essential one (68.6\%) in the educational process by the respondents. Thus, teachers set out demanding value-based requirements for themselves and their colleagues. This can be justified by the results of one of the open-ended questions, which requested to indicate three features of a good higher education teacher. The features characterising the teacher's personality prevailed among the answers (see Table 1). The responses ranged from abstract statements ("it is important to possess value-based attitudes") to listing of specific features related to the personality of a participant in the communication and educational processes. The conveyance of message and professional content of the very message acquire importance in the educational process. Thus, more than half of the respondents (76) stated that that teacher's professionalism is important. This can be explained by the fact that communicating in the educational process, higher education teachers are responsible not only for development of students' general competences but also for their subject-specific preparation. The content of teachers' message should

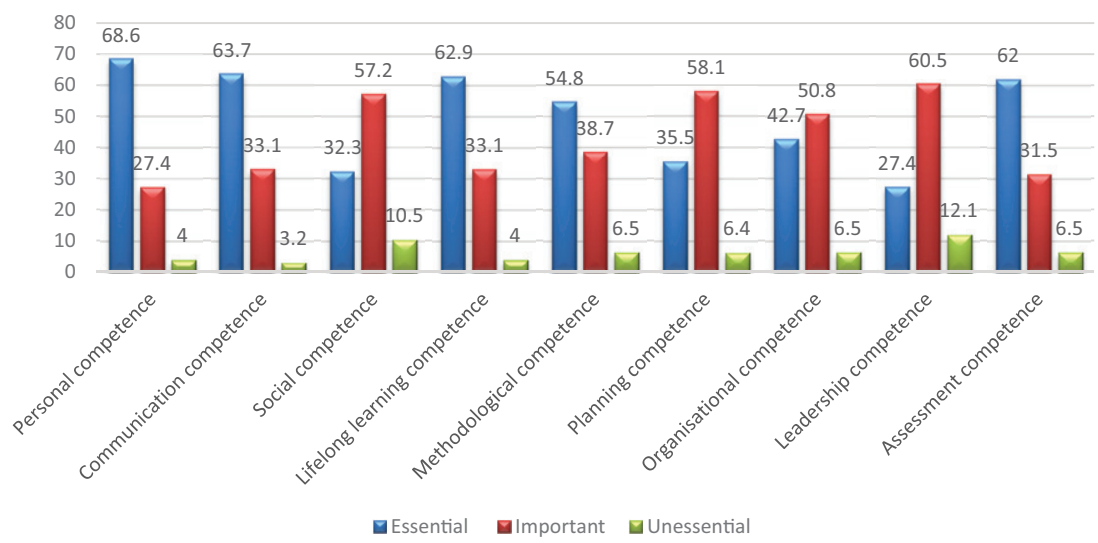

Figure 2. The importance of competences in the educational process (\%) (source: created by authors) 
be constructed on the basis of the relationship between science and practical knowledge. Besides, according to Long et al. (2014), a lecturer's knowledge of subject contributes most to students' satisfaction. It is also important to emphasise that a number of respondents indicated the necessity not be confined to subject-specific knowledge exclusively, i.e. a higher education teacher has to possess a much broader attitude and the personality of a teacher as an erudite is emphasised. Enumerating other personal features, the teachers also related them to the educational process. For example, "responsible", "creating, creative", "creatively modelling the progress of own lecture", "a creator of new ideas" are approached as a responsible attitude developing students' general and professional competences (see Table 1). According to Long et al. (2014), a good lecturer has three dimensions: competence, caring and character. Competence refers to how knowledgeable a source is perceived, caring refers to the extent to which a source expresses concern about another person's well-being, and character refers to how trustworthy and honest he or she is.

It is emphasised that various emotions of the speaker are as important as conveyance of knowledge in the process of teacher-student communication. Loreta Rudaitiene (2004) claims that emotional competence refers to expression of potential and abilities of emotional intelligence, which demonstrates the extent to which a teacher implements this potential learning, taking over and integrating emotional intelligence into own professional activity as an ability to understand, recognise, understand and regulate own emotions and those of others in the academic activities. The list of academic behaviour characteristics of emotionally

Table 1 . The category of personal competence, its subcategory and substantiating quotes (source: created by authors)

\begin{tabular}{|c|c|c|}
\hline Category & Sub-category & Quotes \\
\hline \multirow[t]{5}{*}{$\begin{array}{l}\text { Personal } \\
\text { competence }\end{array}$} & Professionalism & $\begin{array}{l}\text { "An excellent specialist" (2), "well aware of the subject-specific } \\
\text { area" (3), "well aware of the study subject taught" (11), "a pro- } \\
\text { fessional in own area" (3), "a professional in the study field" (2), } \\
\text { "a professional" (19), "a good specialist" (2), "a wealth of profes- } \\
\text { sional knowledge" (3), "professional abilities" (3), "competent" } \\
\text { (14), "professional competence" (2), "subject-specific compe- } \\
\text { tence, subject-specific qualification" (2), "possession of subject- } \\
\text { specific knowledge" (6), "good subject-specific preparation" (2). }\end{array}$ \\
\hline & $\begin{array}{l}\text { Universality of } \\
\text { personality }\end{array}$ & $\begin{array}{l}\text { "An erudite" (16), "educated, sophisticated" (3), "an erudite in } \\
\text { own profession and activities". }\end{array}$ \\
\hline & $\begin{array}{l}\text { Value-based } \\
\text { attitudes }\end{array}$ & $\begin{array}{l}\text { "Possession of value-based attitudes" (3), "retention of values } \\
\text { and resistant to populism, an attitude and values". }\end{array}$ \\
\hline & $\begin{array}{l}\text { Personal qualities } \\
\text { (prevailing) }\end{array}$ & $\begin{array}{l}\text { "Responsible" (12), "creating, creative" (8), "creatively mod- } \\
\text { elling the progress of own lecture", "a creator of new ideas", } \\
\text { "honest" (9), "sincere" (6), "sincere and able to communicate } \\
\text { with students in a simple manner"; "scientifically curious" (7), } \\
\text { "demanding" (6), "innovative" (6). }\end{array}$ \\
\hline & $\begin{array}{l}\text { Other non- } \\
\text { prevailing personal } \\
\text { qualities }\end{array}$ & $\begin{array}{l}\text { "Empiric" (6), "open" (6), "patient" (4), "tolerant" (4), "good- } \\
\text { wiling" (3), "constructive" (3), "flexible" (4), "thorough" (2), } \\
\text { "dutiful" (2), "righteous" (2), "active" (2), "friendly" (2), "intel- } \\
\text { ligent" (2). }\end{array}$ \\
\hline
\end{tabular}


competent teacher consists of such primary competences of emotional intelligence as influence, education of a human being, empathy, service orientation, self-control, precise selfevaluation, self-confidence, team work, collaboration and conflict management. During the research the respondents presented the following personal qualities that are important to a teacher: "empathic", "sincere and able to communicate with students in a simple manner", "open", "spreading positive energy", which show the importance of emotional competence. The research conducted by Yazgan-Sağ and Emre-Akdoğan (2016) depicts that prospective teachers defined the nature of a creative teacher as "attention-grabbing, being able to use his/her tone of voice effectively, and being attentive while approaching students". Thus, they highlighted the behaviours displayed by a teacher as a characteristic of a creative teacher. It could be inferred that they appreciated the good behaviour of a teacher specifically while communicating with students. Such process of communication acquires a higher level and is approached as an establishment of pedagogical interaction between a creative teacher and a student in the educational process.

Communication competence was indicated as the second most important competence in the educational process. This competence consists of a bigger range of subcategories compared to personal competence (Table 2). It is necessary to note that the subcategory "sender's personality" is attributed to communicative competence because it characterises the sender's personality as a universal participant in the process of communication: "charismatic", "admirable personality" and exceptional personality". This example shows that distinguishing three features of a good teacher, the respondents perceive a teacher not only as an educator but characterise him/her as a participant in communication. According to Lotta Kokkonen and Merja Almonkari (2015), communication competence has to influence development of teachers' personal career, publications, financing and other resources as well as labour opportunities; belonging to an academic community depends on interpersonal communication competence of respondents.

The requirements imposed on the teacher are revealed through subcategories, i.e. rhetoric abilities, ability to communicate, to evoke the interest of the audience, to convey knowledge, to present material, to teach clearly and to maintain contact with the audience. It should be pointed out that the teacher's ability to have a joke ("a sense of humour") was mentioned only once. This shows that the respondents do not tend to diversify the process of education with the help of various rhetoric devices or just doubt their benefit. Thus, the teachers supplement the process of education with the elements that are necessary in the lecture ("ability to convey the taught study subject in an interesting way", "to teach in a clear and consistent way", "to establish contact", etc.), though such elements can be attributed to general features of good communication.

It is also closely related to the features of a creative teaching. Cardoso de Sousa (2007) states that the innovative-type of creative teacher are: to be half way to being a good teacher; a communicator first; someone who leaves his or her mark; a seducer, who "inflames", "infects", turns the students into subject matter "addicts". Finally, the typical uncreative teacher seems to be: just someone who delivers the subject matter always the same way, not taking the students' reactions into consideration; who leads them to concentrate on facts and concepts, instead of questioning themselves and the subject matter; a predictable person. 
Table 2. The category of communication competence, its subcategory and substantiating quotes (source: created by authors)

\begin{tabular}{|c|c|c|}
\hline Category & Sub-category & Quotes \\
\hline \multirow[t]{9}{*}{$\begin{array}{l}\text { Communication } \\
\text { competence }\end{array}$} & Ability to communicate & $\begin{array}{l}\text { "Socialising" (11), "a personality, who is attrac- } \\
\text { tive to young people and is capable of communi- } \\
\text { cating"; "communicating with the audience" (2), } \\
\text { "communicative" (14), "able to communicate } \\
\text { with students" (2). }\end{array}$ \\
\hline & $\begin{array}{l}\text { Characterisation of } \\
\text { communication quality }\end{array}$ & $\begin{array}{l}\text { "Correct communication", "correct", "a good psy- } \\
\text { chologist and a perfect communicator", "teaching } \\
\text { with enthusiasm". }\end{array}$ \\
\hline & Rhetorical abilities & $\begin{array}{l}\text { "A good orator" (2), "rhetoric", "ability of public } \\
\text { speaking". }\end{array}$ \\
\hline & Personality of presenter & $\begin{array}{l}\text { "Charismatic" (8), "a fascinating personality" (2), } \\
\text { "an exceptional personality". }\end{array}$ \\
\hline & $\begin{array}{l}\text { Ability to evoke interest of the } \\
\text { audience }\end{array}$ & $\begin{array}{l}\text { "Able to evoke interest of others" (4), "ability to } \\
\text { convey the taught study subject in an interest- } \\
\text { ing way". }\end{array}$ \\
\hline & Ability to convey knowledge & $\begin{array}{l}\text { "Ability to convey knowledge" (3), "able to con- } \\
\text { vey knowledge in an attractive way", "ability to } \\
\text { convey information" (2). }\end{array}$ \\
\hline & $\begin{array}{l}\text { Ability to teach in a clear } \\
\text { manner }\end{array}$ & $\begin{array}{l}\text { "Able to clearly" (2) and consistently teach", "abil- } \\
\text { ity to present teaching material in an interesting } \\
\text { manner", "ability to teach the material in an un- } \\
\text { derstandable way and to present to the audience } \\
\text { (charisma would be necessary as well)", "ability } \\
\text { to explain complex things in a simple way and to } \\
\text { show where/how it can be applied". }\end{array}$ \\
\hline & $\begin{array}{l}\text { Maintenance of relationship } \\
\text { with the audience }\end{array}$ & $\begin{array}{l}\text { "Able to establish and maintain contacts with } \\
\text { the audience", "ability to establish contact and to } \\
\text { maintain it","management of audience", "ability } \\
\text { to engage audience", "ability to moderate". }\end{array}$ \\
\hline & Presentation of material & $\begin{array}{l}\text { "Able to substantiate theory by practice" (4), } \\
\text { "able to present ways of practical application of } \\
\text { the taught subject" (2). }\end{array}$ \\
\hline
\end{tabular}

Lidija Zlatić, Dragana Bjekić, Snežana Marinković, and Milevica Bojović (2014) emphasised that communicative skills of teachers (as well as higher education teachers - the authors' note) have to be developed both at the stages of initial professional training and professional activities. Generalising the content used for development of communicative skills in different universities, the researchers indicated the necessity to include not only communicative but also educational themes (communication in a small group and class, teacher communication styles and styles of teaching management) into it.

During the research the teachers were asked to evaluate teachers' abilities according to their significance. Figure 4 presents the abilities, which make up the content the competences analysed in the article as well as that of other ones. It can be stated that the ability to encourage students to discuss, analyse, formulate problem-based question and generate ideas, 
which belongs to the methodological ability, is the most significant (84.7\%). This is achieved only being able to properly communicate with students. The second most important ability was related to listening to and hearing the opinion of others (79\%), which is assigned to the communication competence. The third most important ability indicated by the respondents (77.4\%) refers to the capability of relating theoretical material with practical application that is associated with methodical competence. Following the results of the student research conducted by Gintaute Žibenienè (2017), it can be stated that according to the first year students of physical education a competent teacher has to demonstrate such competences as didactic, student motivation and support provision, student awareness and recognition, common cultural, communication and cooperation ones. The research also revealed that a competent teacher has to communicate in a kind and respectful manner.

Other evaluations of abilities are presented in Figure 3.

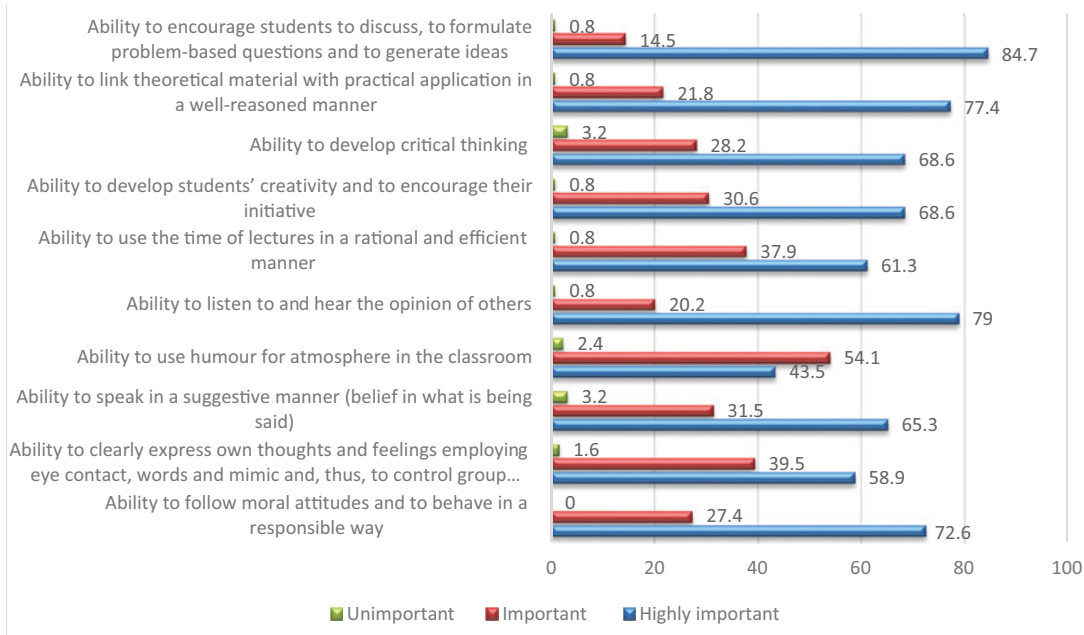

Figure 3. Abilities in the educational process according to their significance (source: created by authors)

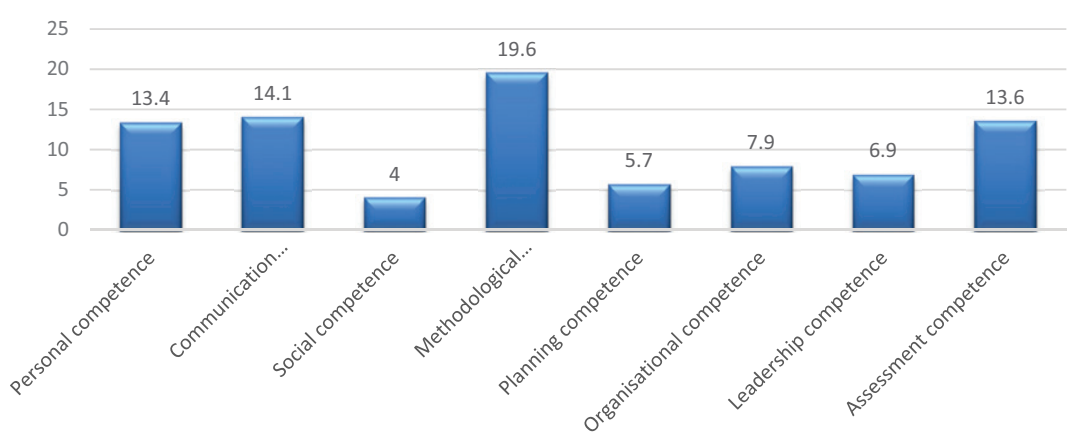

Figure 4. The need for improvement of competences (source: created by authors) 
The respondents were also asked to mark the competences, which, in their opinion, have to be improved. Generalising the results, it can be concluded that the teachers see the necessity to improve methodological competence (19.6\%), communication competence $(14.1 \%)$ and assessment competence (13.6\%), which is a component of methodological competence (see Figure 4). Thus, teachers not only understand the importance of communication and educational competences in the educational process but also demonstrate a need for their continuous improvement.

\section{Conclusions}

Analysing the theoretical and research results, it can be noted that there is a direct relationship between the communication and educational competences whose strong relationship inspires creativity in the study process. Communicating with students, higher education teachers not only communicate but also establish a pedagogical interaction, which requires educational competence. The research results revealed that the two interrelated competences, i.e., personal and communication competences, are the most significant for teachers of higher education institutions. Personal competence embraces human values and various personal qualities that include not only positive characteristic features but professionalism as well. While analysing communication competence there appear some qualities that may be characteristic to a person or not, e.g., erudition, charisma, etc. Therefore, higher education teachers who have developed their communication competence manage the educational process in a more efficient way. The interrelation between educational and communication process is especially enhanced by a creative personality of the teacher, i.e., a teacher who is able to not only carry out professional assignments creatively choosing and employing new strategies on methodology but also creating them himself or herself. Such creative approach enhances students' active participation and satisfaction in the study process. Communicating in the educational process, higher education teachers become not only conveyors of subject-specific or professional knowledge but can also have influence on the student as a personality. This creates obligation to constantly improve subject-specific, educational and communication competences. It should be noted that teachers not only perceive the importance of communication and educational competences but also demonstrate a need for their lifelong improvement.

\section{References}

Aukštkalnytė, D. (1999). Komunikacinė pedagogų kompetencija kaip pedagoginio bendravimo prielaida. Acta Paedagogica Vilnensia, 6, 12-22.

Bainbridge Frymier, A., \& Houser, M. L. (2000). The teacher-student relationship as an interpersonal relationship. Communication Education, 49(3), 207-219. https://doi.org/10.1080/03634520009379209

Baršauskienė, V., Almonaitienė, J., Lekavičienė, R., \& Antinienė, D. (2011). Žmonių santykiai organizacijose. Kaunas: Kauno technologijos universiteto leidykla „Technologija“.

Cardoso de Sousa, F. (2007). Teachers' creativity and effectiveness in higher education: Perceptions of students and faculty. The Quality of Higher Education, 4, 21-37. 
Jovaiša, L. (2007). Enciklopedinis edukologijos žodynas. Vilnius: Gimtasis žodis.

Kokkonen, L., \& Almonkari, M. (2015). Teaching networking: An interpersonal communication competence perspective. In J. Jalkanen, E. Jokinen, \& P. Taalas (Eds.), Voices of pedagogical development - expanding, enhancing and exploring higher education language learning (pp. 31-56). Dublin: Research-publishing.net.

Leikin, R. (2009). Exploring mathematical creativity using multiple solution tasks. In R. Leikin, A. Berman, \& B. Koichu (Eds.), Creativity in mathematics and the education of gifted students (pp. 129-145). Rotterdam: Sense Publishers.

Long, Ch. S., Ibrahim, Z., \& Owee Kowang, T. (2014). An analysis on the relationship between lecturers' competencies and students' satisfaction. International Education Studies, 7(1), 37-46.

Palujanskiené, A. (2010). Ugdomoji sąveika ugdymo dalyvių psichikos ypatumų aspektu. Kultūra Ugdymas - Visuomene, 3, 16-21.

Petrovna Gladilina, I. (2016). Creativity in the structure of professionalism of a higher school teacher. International Journal of Environmental \& Science Education, 11(8), 1691-1699.

Petrulyte, A. (2008). Bendravimo psichologija. Vilnius: Vilniaus pedagoginio universiteto leidykla.

Pukelis, K., Savickienè, I., Danilevičius, E., Slavinskienè, A., Lapėnienė, A., Baltrušaitytė, G., Stasiūnaitienè, E., \& Vyšniauskytė-Rimkienè, J. (2011). I problemu sprendima orientuotu studiju metodai. Kaunas: Vytauto Didžiojo universitetas.

Rudaitienė, L. (2004). Dėstytojo emocinès kompetencijos raiškos ypatumai. Acta Paedagogica Vilnensia, $12,81-94$.

Tidikis, R. (2001). Dėstytojų ir studentų santykių tobulinimo kryptys. Iš Aukštojo mokslo sistemos ir didaktika: konferencijos pranešimu medžiagos (pp. 381-387). Kaunas: Kauno technologijos universiteto leidykla „Technologija“.

Yazgan-Sağ, G., \& Emre-Akdoğan, E. (2016). Creativity from two perspectives: Prospective mathematics teachers and mathematician. Australian Journal of Teacher Education, 41(12), 25-40. https://doi.org/10.14221/ajte.2016v41n12.3

Zlatić, L., Bjekić, D., Marinković, S., \& Bojović, M. (2014). Development of teacher communication competence. Procedia: Social and Behavioral Sciences, 116, 606-610. https://doi.org/10.1016/j.sbspro.2014.01.265

Žibènienè, G. (2017). Kompetentingo destytojo samprata, Lietuvos edukologijos universiteto kūno kultūros specialybės pirmo kurso studentų požiūriu. Sporto mokslas, 1(87), 16-23. https://doi.org/10.15823/sm.2017.3

\title{
KOMUNIKACIJOS IR EDUKACIJOS SANTYKIS PER KÜRYBIŠKĄ DĖSTYTOJO ASMENYBĘ
}

\author{
Vida NAVICKIENĖ, Živilè SEDEREVIČIŪTĖ-PAČIAUSKIENĖ, \\ Ilona VALANTINAITÉ, Viktorija ŽILINSKAITÉ-VYTIENE்
}

\begin{abstract}
Santrauka
Straipsnyje analizuojamos komunikacinių ir edukacinių procesų sąsajos aukštojo mokslo kontekste. Išsamiai pristatomi kiekybinio tyrimo, kuriame buvo naudoti ir atviri apklausos klausimai, rezultatai, rodantys Lietuvos aukštųjų mokyklų dėstytojų požiūrị ị komunikacijos svarbą edukaciniame procese. Nors dèstytojai turetų būti išsiugdę ịvairias kompetencijas: asmeninę, komunikacinę, socialinę, nuolatinio mokymosi, metodinę, planavimo, organizavimo, vadovavimo, vertinimo, tačiau jie išskyrè
\end{abstract}


tik keletą jų kaip svarbiausių. Tyrimas parodė, kad dėstytojams svarbiausios yra trys kompetencijos - asmenine, komunikacinè ir nuolatinio mokymosi, kurios atskleidžia ir pagrindžia glaudžias komunikacijos ir edukacijos procesų sąsajas. Dėstytojai ne tik suvokia komunikacinès ir edukologinès kompetencijų svarbą edukaciniame procese, bet ir išreiškia poreikị jas nuolat tobulinti. Analizuojant teorinius ir tyrimo metu gautus rezultatus, teigtina, kad edukaciniame procese yra tiesioginis komunikacinès ir edukologinès kompetencijų ryšys.

Reikšminiai žodžiai: komunikacinès kompetencijos, kūrybiškas dėstytojas, edukacinès kompetencijos, aukštasis išsilavinimas, dėstytojo komunikacija. 